\title{
The Political Economy of US Military Spending*
}

\author{
MIROSLAV NINCIC \\ Department of Political Science \\ University of Michigan
}

\author{
THOMAS R. CUSACK \\ International Institute for Comparative \\ Social Research, Science Center Berlin
}

\begin{abstract}
The causes of the dramatic rise in military spending in the post-war era have been the subject of much political and academic controversy. No extant formulation seems to provide a compelling explanation of the dynamics involved in the levels of, and rates of change in, such spending.

In light of this, the authors develop a new model, based mainly on a political-business cycle argument, to account for these dynamics. The basic proposition in this model is that variations in national defense spending arise from political considerations which are related to real and desired conditions within the national economy. Applying this model to the experience of the United States 1948-1976, the authors show that it has a large measure of empirical validity. If one removes the effects of war-time mobilization, it is clear that for the United States the principal driving forces in military spending dynamics were (1) the perceived utility of such spending in stabilizing aggregate demand, (2) the political or electoral value of the perceived economic effects arising out of such spending, and (3) the pressures of institutional-constituency demands.
\end{abstract}

\section{Introductory remarks}

Both because of its bearing on national security and because it is so large and visible, defense spending has been the frequent object of both political and academic controversy in the US. The issue which has commanded particular attention in the foreign policy literature concerns the causes of the regular post-war increases in such expenditure. It perhaps reflects the misleading simplicity of the problem that, despite the elegance of theoretical formulations and the sophistication of analytic techniques employed, there is as yet no compelling explanation of the levels of, and rates of change in, military spending in the United States. The question of the domestic consequences of defense outlays has also been occasionally addressed, although frequently from an excessively doctrinaire perspective and with results barely more conclusive than

* We thank Professor Karl W. Deutsch and Catherine Kelleher for their helpful comments and suggestions. Our thanks also to Ms. Sandra Di Carlo for typing and editing the final manuscript. those concerning its determinants.

Our first task in this paper will be to account for variations in US military spending during the past three decades. We begin by providing a brief assessment of the extant analytical frameworks bearing on this issue. Following that, we construct an alternative, though partly complementary, explanatory structure of our own. Specifically, we examine the proposition that variations in defense spending arise from political consideration which are related to real and desired conditions within the national economy. Finally, we ask how successfully military spending functions as a tool of macro-economic policy as far as the reduction of unemployment is concerned.

\section{Compulsion or impulsion?}

Two principal types of explanation have been advanced to account for changing military expenditures: the first relies primarily on influences exogenous to the nation, the second focuses on internal considerations.

Most writers in the first tradition rely, to 
a greater or lesser extent, on the well known and pioneering work of Lewis Richardson ${ }^{1}$ who presented the first formal statement of the dynamics of arms races. In a model combining intuitive plausibility and theoretical parsimony, he suggested that the driving force behind fluctuations in military spending was the continuous and apparently ineluctable process of action and reaction between two rival nations. The model was cast in the form of linear differential equations from which equilibrium conditions were deduced.

Richardson's thought has dominated the arms race literature and is unlikely to be completely abandoned in the near future. There are, neverthelss, problems with this perspective. We are, first of all, aware of no compelling empirical evidence that has been adduced in support of the 'action-reaction' hypothesis. Furthermore, the model pays little attention to the matter of how actual decisions are made or to the institutional procedures surrounding them. Thus, we are told nothing of the actors and interests involved, or of the perceptions and motivations of the relevant parties.

This latter shortcoming is at least partly remedied by the second of the two major perspectives on military expenditures, as it relies primarily on certain organizational dynamics within the state. The basic idea is that the decision to acquire additional military resources is imbedded in an organizational and bureaucratic setting. ${ }^{2}$ The complexity of the decisionmaking process will lead to the establishment of routinized practices, the choice of predictable figures for budgetary requests (which tend to be a simple function of past requests), and just as predictable congressional modifications of the original figures. Regularity over time is the outcome; as a result, the best predictor of new increments to military expenditure are simply those which obtained in the immediate past. ${ }^{3}$

Attempts at explicitly evaluating the relative performance of the two contending approaches tend, in general, to favor the second one. Charles Ostrom (1977) recently conducted a quantitative study of the respective predictive powers of the two models in the context of US-Soviet defense spending. On the basis of the results of an econometric analysis, that author found it very difficult to distinguish empirically the two types of effects. The bulk of the evidence is, however, more conclusive. Albert Wohlstetter, on the basis of arguments presented in two articles $(1974 \mathrm{a}, \mathrm{b})$, has concluded that: 'The iron law that is supposed to govern strategic action (for Every Action, there is An Opposing Equal or Greater-than-Equal Reaction) is made in fact of plastic' (1974b, p. 49). One of the present authors, in a study that sought to deal with many of the problems of previous investigations of the Richardsonian paradigm, found little evidence to lend support to the 'action-reaction' hypothesis. However, using a fairly elaborate model of the internal processes of the state, he found support for the notion that organizational and fiscal factors play an important role in generating arms level changes. (See Cusack, 1978.) A recent study by Kenneth Organski, Jacek Kugler, and Daniel Fox (1978), which statistically compared the performance of the two models as far as US and Soviet procurement of strategic arms is concerned, also found exogenous considerations less important than those of a domestic nature.

Thus, it would seem on the basis of extant research that internal considerations have clear causal primacy in accounting for military spending. Yet even here we have ample reason to be dissatisfied with the existing propositional framework and knowledge claims. On purely empirical grounds, the paradigm suggests a temporal continuity devoid of abrupt changes something clearly inconsistent with the historical record. The time-series plot of both absolute levels of defense spending in the United States during the past several decades and of annual changes in these levels (see Fig. 1) supports this charge. The simple 'autoregressive' movement suggested 
by the 'organizational' model implies a relatively smooth progression of expenditures rather than the jagged trajectory actually displayed. Furthermore, there is nothing in the model which would explain the major accelerations of the early 1950 s and late $1960 \mathrm{s.}^{4}$

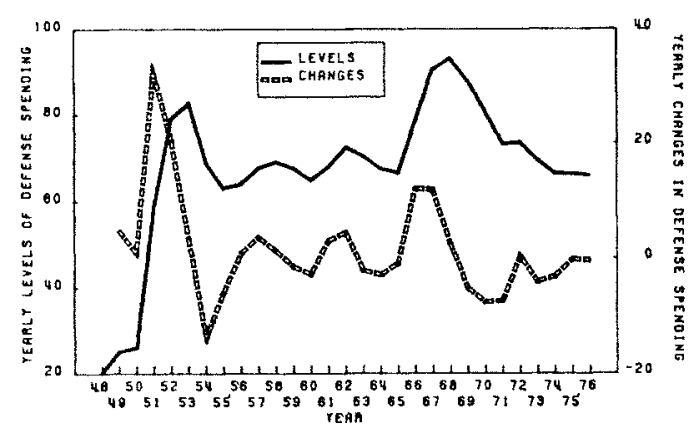

Fig. 1. US Defense Spending.

The major problem, from our point of view, is simply that the range of theoretical considerations addressed has so far been excessively narrow. Despite the plausibility of the postulated effects of organizational and bureaucratic politics, we find it hard to believe that this is all there is to domestic influences. The primary need might be for new avenues of inquiry: and we shall propose one which relies on the conjunction of political and economic forces in explaining US defense spending.

\section{An alternative approach}

Before we can advance our own, statistically verifiable propositions, a number of considerations must be introduced for control purposes. Contemporary research has, as noted above, suggested that a useful predictor of fluctuations in defense spending is given by the simple autoregressive process whereby current changes are a function of those in the immediate past. We therefore accept as a first hypothesis introduced for control purposes that:
(1) $\delta\left(\mathrm{m}_{\mathrm{t}}\right) / \delta\left(\Delta \mathrm{m}_{\mathrm{t}-1}\right)>0$, where $\Delta \mathrm{m}_{\mathrm{t}}$ is the change in the real value of US defense spending between the past and the current year, ${ }^{5}$ and $\triangle m_{t-1}$ is the change in the real value of US defense spending between the past year and the year preceding it.

An additional variable which should be introduced for purposes of statistical control is US involvement or non-involvement in an armed conflict claiming its military resources. While the self-evident nature of this consideration might account for its neglect in much empirical research, we feel that it would be rash, from a statistical point of vie $N$ at least, not to include it in an explanatory schema. An additional proposition is therefore the following:

(2) $\partial\left(\triangle w_{t} / \partial w_{t}>0\right.$, where $w$ reflects the extent of US war involvement in the year $t$.

A glance at Fig. 1 suggests that increases in military expenditures are not of a uniform level for the entire duration of the wars. During both the Korean and the Vietnam wars, initially very high increases were followed by very low increments for the rest of the wars' durations. On inductive examination, it appeared that the large increases occur during the first two years of the war, diminishing thereafter. Thus, a peak in the size of annual increases is reached after two years (or was, in any case, for these two wars); a period which seems to correspond to the time necessary to mobilize and deploy forces for limited conventional warfare. Before and after the peak, however, changes seem to proceed exponentially (albeit in different directions). Without the guidance of any formal theory of the process of conventional wartime mobilization, but with some inductive experimentation, ${ }^{6}$ we conjectured that the process could be represented by a function of the following simple exponential form:

(3) $w_{t}=c \times 1 / 2\left(t_{w}-t_{n}\right)$ where, $t_{w}$ is the current war year (e.g., $t_{w}=3$ if this is the third year since the beginning of the war), 
$t_{p}$ is the peak year with (in our case) a constant value of 2 , $\mathrm{c}=1$, if $\mathrm{t}$ is a war year $=0$, otherwise

Implied, therefore, is a process wherein the size of annual increments to defense spending increases exponentially during the first two years of the war and tapers off asymptotically thereafter.

Both $\triangle \mathrm{m}_{\mathrm{t}-1}$ and $\mathrm{w}_{\mathrm{t}}$ are interesting, indeed obvious, predictors of fluctuations in $\triangle \mathrm{m}_{\mathrm{t}}$. We will, however, attempt to probe deeper by examining the extent to which domestic political functions might be performed by accelerating or decelerating military spending in the United States. Since final decisions on military spending are taken by the President and Congress, i. e. by elected officials, a useful starting point might be to investigate which (if any) political gains or costs they might experience as a result of such fluctuations.

A promising line of inquiry is suggested by several recent studies which assert that national economic performance is a major determinant of electoral outcomes. The specific relevance of such conclusions for our purposes resides in the existence of an additional body of literature which seeks to link military spending to economic performance. To guide our efforts we will, therefore, entertain three questions:

(1) Does economic performance influence electoral outcomes for incumbent political authorities?

(2) If so, do incumbents attempt to manipulate the economy for their electoral ends?

(3) Do military expenditures affect economic performance?

If there were reason for an affirmative answer to each of these questions, then we could additionally inquire:

(4) Is there reason to believe that military spending might, at least partially, be used by incumbents for political-electoral purposes?

Let us begin with the first question. A number of studies indicate that electoral outcomes are responsive to objective economic conditions. Gerald Kramer (1971), in an innovative study, sought to relate variations in real and money income, unemployment, and rate of inflation to the outcome of congressional elections. His conclusion, based on a sound statistical analysis, was that economic fluctuations do in fact represent important influences on congressional elections, with economic upturn helping the congressional candidates of the incumbent party, and economic decline benefiting the opposition' (ibid, p. 40). The most significant impact, according to Kramer, is produced by changes in per-capita income (with a $10 \%$ increase in real personal income inducing a $4-5 \%$ gain in the incumbent parties' congressional vote). In a more recent study of mid-term congressional elections, Edward Tufte (1975) concluded that, controlling for presidential popularity, a change in disposable per-capita income of $\$ 180$ (in constant terms) would be expected to yield a $6 \%$ change in the number of votes obtained by the incumbent party in mid-term elections. In subsequent research, Tufte generalized these results to the onyear congressional vote as well as to presidential elections. ${ }^{7}$ In sum, it would appear that, at least in the US context, economic performanoe has an important influence on electoral outcomes for incumbent politicians. The answer to our first question is therefore affirmative.

What about the manipulation of the economy for political profit? The finding that economic conditions affect the electoral performance of those in power quite naturally suggests the possibility that incumbents, in a post-Keynesian era, might actually manipulate economic conditions so as to increase their chances of continued incumbency. Some research by William Nordhaus and Tufte indicates that such is indeed the case. The latter, in the most popular piece of work on the subject, investigated the possibility that incumbents may seek to determine the location and timing of economic benefits in promoting the fortunes of their party and friends's. His findings indicate the existence within the United States 
of a 'political business cycle' conceived of as a successful attempt to make the timing of improvements in national macroeconomic performance correspond to the electoral cycle. For example, postwar increases in real disposable income were shown to coincide with election years (particularly on-year elections with an incumbent president seeking a second term). Furthermore, unemployment rates were found to decline in the two years preceding a presidential election (Tufte, 1978, pp. 3-28).

There is therefore reason to believe that elected officials in the United States perceive the relevance of economic fluctuations to their political fortunes and, as a consequence, attempt to act on them with the specific aim of affecting the timing of the business cycle. The second of our four questions seems also to merit an affirmative answer. Furthermore, if military spending has, as some claim, a significant economic impact in the US, then these expenditures might also be partly accounted for by such domestic political considerations. The next question to address then concerns the impact of defense spending on economic performance.

What can we say about the effects of military outlays on national economic conditions? The basic proposition underlying much of the written work on this issue is the simple Keynesian statement that recessions occur when aggregate demand within the economy falls short of productive capacity. The consequence of this is inventory accumulation, unemployment, and sluggish or negative growth. As private consumption and especially investment are usually insufficient to maintain an adequate level of aggregate demand, there is a need to increase this demand through governmental expenditures for goods and services. In a 'mixed economy', military expenditures are considered by some to be rather well suited for such purposes. In the contemporary United States, according to Hitch and McKean (1961, p. 69):
Defense spending, which often amounts to 10 percent of GNP nowadays, is a significant component of government and total spending. Where government spends such an amount for national security (or for anything else) it tends to buoy up total spending. The existence of this demand makes a deficiency of total demand less probable. Moreover, it facilitates the application of other antideflationary measures, like the injection of additional money into the economy.

Somewhat further to the left, John Kenneth Galbraith (1967, p. 235) points out:

If a large sector of the economy supported by personal and corporate income taxation is the fulcrum for the regulation of demand, plainly military expenditures are the pivot on which the fulcrum rests.

While radical economists use the concept of 'absorptive capacity' rather than aggregate demand, their conclusion concerning the economic role of defense spending is similar. James Cypher (1977, p. 1; see also Smith, 1977), for example, maintains that for the US economy:

The fluctuation in GNP can be accounted for, to a considerable degree, by fluctuation in military expenditure. Postwar stabilization has (for the most part) been achieved by manipulating military expenditures.

It is of course one thing to quote other authors and another to present one's own quantitative proof. While a complete test of the relation between US economic growth and military outlays is beyond the scope of this paper, we can report on a simple test of their statistical association. The most prevalent measure of national economic performance is, without doubt, the growth in GNP per capita. Furthermore, most people seem to think of and refer to fluctuations in GNP per capita in percentage terms, and of fluctuations in military expenditures in absolute terms (e.g., an increase of $\$ 5$ billion). If changes in percent growth of GNP per capita seemed to be empirically associated with changes in levels of military spending, a causal connection might well be established both in the public's and the politicians' eyes. It would also suggest, pending a more thorough macroeconomic examination, ${ }^{9}$ that 
they may well be right. We formulated a simple econometric model of the form:

(4) $\ln \left(E_{t}\right)=k+\delta m_{t}+u_{t}$, where, $m_{t}$ represents the level (in real terms) of US military spending in year $t$, and $E_{t}$ represents the real value of GNP per capita in year $t .^{10}$

In a bivariate relation, where the dependent variable is represented by its natural logarithm and the independent variable by its absolute value, it can be demonstrated that the regression coefficient (multiplied by 100 ) may be interpreted as approximating the percentage change in the former associated with a unit change in the latter. In other words, $\delta$ may be interpreted as $\left(\triangle \mathrm{E}_{\mathrm{t}} / \mathrm{E}_{\mathrm{t}}\right) / \triangle \mathrm{m}_{\mathrm{t}}{ }^{11}$ In the present formulation $\triangle \mathrm{m}_{\mathrm{t}}$ is of the magnitude of one million dollars measured in real terms.

A preliminary estimation using ordinary least squares yielded considerable firstorder autocorrelation $(\mathrm{DW}=0.62)$. We therefore reestimated the model using the Cochran-Orcutt iterative procedure. The results are displayed in Table I. While the

Table I. Military spending and economic growth in the US, 1948-1976

\begin{tabular}{lccc}
\hline Variable & Coefficient & $\mathrm{r}$ & $\mathrm{t}$ \\
$\mathrm{m}_{\mathrm{t}}$ & $\delta=+0.004$ & +0.52 & 3.19 \\
$\mathrm{k}=6.47$ & $\mathrm{df}=27$ & $\mathrm{R}^{2}=0.27$ \\
\hline
\end{tabular}

overall fit is quite good for a simple bivariate model, the estimated coefficient of .004 suggests that a $1 \%$ annual increase in GNP per capita in the United States is associated with a $\$ 2.5$ billion increase in military spending. The statistical significance of the coefficient (which is more than three times larger than its standard error) is also encouraging. While the extreme simplicity of the model allows us to claim no more, we do believe that this association might generally be perceived as reflecting a causal link in the eyes of the relevant actors.
While we will return to the relation between macroeconomic performance and military spending later in this study, we now have some reason to believe the following three statements (which correspond to our first three questions): (a) objective economic conditions affect the incumbent party's electoral prospects; (b) incumbents seem to manipulate these conditions so as to make periods of economic expansion precede important election years; and (c) economic growth has, between 1948 and 1976 , been positively associated with increases in defense spending. The question of whether variations in military spending are linked to electoral-economic considerations now seems to follow naturally. Rational political incumbents, realizing that economic conditions affect their fate, will seek to manipulate the economy to their benefit. Since military spending, which is clearly under their control, appears to promote economic conditions beneficial to their political fortunes, should we not expect the incumbents to use this fiscal tool to their advantage?

Despite what we have said so far, the suggestion that defense spending, an instrument of national security, is manipulated for domestic political purposes might seem rather far-fetched to some. There is, however, some anecdotal evidence which points to its credibility. For example, in Six Crises (1962, p. 309), Richard Nixon recalls that in March 1960, during the electoral campaign, Arthur Burns visited him and:

expressed great concern about the way the economy was then acting... Burns' conclusion was that unless some decisive governmental action were taken, and taken soon, we were heading for another dip, which would hit its low point in October, just before the elections. He urged strongly that everything be done to avert this development. He urgently recommended that two steps be taken immediately: by loosening up credit and, where justifiable, by increasing spending for national security. The next time I saw the President, I discussed Burns' proposals with him and he in turn put the subject on the agenda for the next Cabinet meeting. [our italics] 
Although endorsed by Nixon, Burn's suggestion eventually did not prevail - apparently because the economic situation was not deemed perilous enough. Yet the potential utility of such methods was clearly perceived - even in an administration noted for its conservative approach to fiscal and macroeconomic questions.

If our line of reasoning is substantially correct, one would expect to see particularly high growth in levels of defense spending in the years preceding on-year elections. This would be due to a vigorous attempt by the incumbents at promoting economic expansion, and thus an increase in income and employment levels, at a time when this seems politically most beneficial. In the years following the election, we would expect decelerating rates of military growth as the electoral incentive is temporarily removed (and as considerations of inflation take precedence). During the four-year period between two on-year elections we would therefore expect that changes in defense spending would, ceteris paribus, manifest a cyclical pattern marked by early deceleration and later acceleration. This follows from two assumptions. First, military expenditures are a useful way of acting on aggregate demand and hence of pursuing stabilization policies. ${ }^{\mathbf{1 2}}$ Secondly, politicians, who are dealing with an economy constrained by a tradeoff (or the appearance of such) between unemployment and inflation, and facing an electorate for whom growth and employment in the most recent period is paramount, will distribute the terms of the tradeoff in such a way as to derive the greatest political benefit. Approaching on-year elections will lead to expansionary policies; but, following an election, the need to promote growth and full employment will be replaced by a need to curb inflation generated by the previous expansionary decisions. ${ }^{13}$ This retrenchment cannot be implemented overnight, yet the shift should be noticeable. Formally then:
(5) $\partial\left(\triangle m_{t}\right) / \partial\left(V_{t}\right)>0$, where, $V_{t}=1$ if $t$ precedes or coincides with an on-year election.

$=-1$ if $\mathrm{t}$ succeeds by one or two years the election.

Of course, not all macroeconomic policy is geared to electoral goals. Stabilization is an objective pursued in its own right and, to the extent that military spending serves the specific function of compensating for inadequacies in aggregate demand, we would also expect to observe a negative relation across time between fluctuations in such spending and private consumption and investment expenditures. Formally:

(6) $\partial\left(\triangle m_{t}\right) / \partial \triangle(c+i)_{t}<0$, where, c, i represent private consumption and investment spending. ${ }^{14}$

To recapitulate, we predicted that the change in military spending which had occurred during the previous year would be an important determinant of the change occurring in the present year; the process of wartime mobilization would generate changes of an exponential form; the time separating $t$ from the nearest on-year election would affect spending such that deceleration would occur toward the beginning of the cycle and acceleration would occur toward the end of the four-year period; finally, changes in aggregate private demand would call forth an opposite change in military spending. Bringing together inequalities $1,2,5$ and 6 , we obtain the following predictive model for changes in US military expenditures:

(7)

$\Delta \mathrm{m}_{\mathrm{t}}=\mathrm{k}+\delta_{1}\left(\Delta \mathrm{m}_{\mathrm{t}-1}\right)+\delta_{2} \mathrm{w}_{\mathrm{t}}+$
$\delta_{3} \mathrm{~V}_{\mathrm{t}}+\delta_{4} \Delta(\mathrm{c}+\mathrm{i})_{\mathrm{t}}+\mathrm{u}_{\mathrm{t}}$, where, $\mathrm{k}$
is a constant term reflecting the 'long
run' tendency of US military spend-
ing to increase independently of any
of the other variable considerations,
$\mathrm{u}_{\mathrm{t}}$ is a stochastic term, and, the other
terms are as defined above.


The temporal progression of $\mathrm{w}_{\mathrm{t}}$, as well as $\mathrm{V}_{\mathrm{t}}$ and $\triangle(c+i)$, is displayed in Fig. 2.

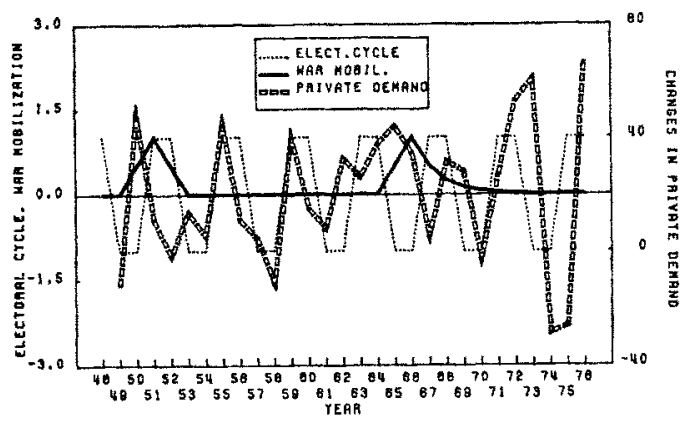

Fig. 2. Predictors of changes in defense spending.

\section{Statistical results}

The results of a statistical estimation of the model and its parameters are presented in Table II. The general and encouraging con-

Table II. Predictor model for US defense spending, 1948-1976

\begin{tabular}{llll}
\hline Variable & Coefficient & $\mathrm{t}$ & Partial $\mathrm{r}$ \\
\hline$\Delta \mathrm{m}_{\mathrm{t}-1}$ & $\delta_{1}=+0.25$ & 2.06 & +0.40 \\
$\mathrm{w}_{\mathrm{t}}$ & $\delta_{2}=+21.09$ & 5.78 & +0.78 \\
$\mathrm{~V}_{\mathrm{t}}$ & $\delta_{3}=+2.03$ & 1.95 & +0.38 \\
$\Delta(\mathrm{c}+\mathrm{i})_{\mathrm{t}}$ & $\delta_{4}=-0.06$ & 1.37 & -0.28 \\
\hline $\mathrm{k}=-1.24$ & $\mathrm{df}=22$ & Durbin's $\mathrm{h}=0.84$ \\
$\mathrm{R} 2=0.71$ & & & \\
\hline
\end{tabular}

clusion is that our predictions have met with a good deal of success. Thus, the coefficients for both the 'organizational' and war variables take on positive signs and are several times larger than their standard errors as reflected in the magnitude of their $t$ values. The coefficient for the lagged value of changes in military spending suggests that the scope of incrementalism is rather narrow. The coefficient for war mobilization indicates the following expected sequence in spending increases from the outset of the conventional war: 10.5 billion (in real,
1972, dollars), 21.0, 10.5, 5.3, 2.6, .., through the end of the war. No decrease in expenditures in the years succeeding the war is expected. This last point, of course, concords with the suggestions of a 'ratchet effect' in the military effort of states involved in a war (see Russett, 1970). War increases the military effort; and, while this increase tapers off progressively, the level of post-war spending will be significantly greater than that in the pre-war period (ceteris paribus).

More relevant to our immediate concerns are the other results. The electoral coefficient's sign is in the predicted direction and its magnitude is nearly twice that of its standard error. Thus, military spending certainly seems to fluctuate in accordance with the swing of the electoral cycle. Military spending is cut back at an expected rate of $\$ 2$ billion per-annum after on-year elections and expanded at a similar rate in the two years prior to those elections - again, other things being equal.

The sign of the coefficient for fluctuations in aggregate private demand is in the predicted direction, indicating an expected $\$ 60$ million dollar increase in defense spending resulting from a $\$ 1$ billion dollar decline in private consumption and investment. A corresponding increase in private demand would call forth an expected decrease in military spending under ceteris paribus conditions. The estimated coefficient is, however, quite unstable: in fact, a $90 \%$ confidence interval would place it somewhere between 0.015 and -0.14 (although it is centered on -0.061 ).

Since we are dealing with time series data, we should be concerned with the problem of autocorrelation among the residuals which might vitiate some of our statistical findings. As we have a lagged endogenous variable in our set of predictor variables, a Durbin-Watson statistic is not an appropriate measure of serial correlation and so we relied on the Durbin's h statistic instead (see Johnston, 1972, pp. 309-313). The value of this statistic $(0.84)$ indicates that 
first order autocorrelation is unlikely to be a problem. A visual examination of higher order autocorrelation coefficients suggested no other autoregressive or moving average process among the errors.

In sum, we believe that our model of changes in US defense spending does a good job. We are able to account for over $70 \%$ of the variance, and most of our variables perform very well. In addition, the set of findings for total military spending (net of transfers and interest payments) holds generally across the major categories of this spending effort. In Table III and Table IV, we present the results from analyses of the two principal components of defense spending: spending for capital goods items (purchases of equipment and facilities) and labor items (compensation of military and civilian employees)..$^{15}$

The model is able to account for $52 \%$ of the variance in capital goods purchases and $72 \%$ of the variance in direct personnel expenditures. More interesting are the coefficient estimates.

Table III. Predictor model for US defense spending on capital items, 1948-1976*

\begin{tabular}{lccc}
\hline Variable & Coefficient & $\mathrm{t}$ & partial $\mathbf{r}$ \\
\hline \multicolumn{1}{c}{$\mathrm{c}^{* *}$} & & & \\
$\Delta \mathrm{m}_{\mathrm{t}-1}$ & $\delta_{1}=+0.25$ & 1.39 & +0.28 \\
$\mathrm{w}_{\mathrm{t}}$ & $\delta_{2}=+5.93$ & 4.00 & +0.65 \\
$\mathrm{~V}_{\mathrm{t}}$ & $\delta_{3}=+1.01$ & 2.10 & +0.41 \\
$\Delta(\mathrm{c}+\mathrm{i})_{\mathrm{t}}$ & $\delta^{4}=-0.04$ & 2.02 & -0.40 \\
\hline $\mathrm{k}=0.03$ & $\mathrm{~d} \mathbf{f}=\mathbf{2 2}$ & \multicolumn{2}{c}{$\mathbf{R}^{2}=0.52$}
\end{tabular}

* Model estimated using Cochran-Orcutt technique

** mc represents purchases for equipment and facilities

The lagged dependent variable's coefficient in the equation for capital expenditures is not highly significant, though in the predicted direction. In the second equation, this same variable performs considerably better. The obvious conclusion is that spending on compensation of personnel is not very volatile across time (indeed it seems to follow a predictable and steady upward pro-
Table IV. Predictor model for US defense spending on compensation for defense personnel, 19481976.

\begin{tabular}{llll}
\hline Variable & Coefficient & $\mathbf{t}$ & partial $\mathbf{r}$ \\
\hline \multicolumn{1}{c}{$\mathrm{p}^{* *}$} & $\delta_{1}=+0.35$ & 2.80 & +0.51 \\
$\Delta \mathrm{m}_{\mathrm{t}-1}$ & $\delta_{2}=+5.49$ & 5.72 & +0.77 \\
$\mathrm{w}_{\mathrm{t}}$ & $\delta_{3}=+0.87$ & 2.79 & +0.51 \\
$\mathrm{~V}_{\mathrm{t}}$ & $\delta_{4}=-0.017$ & 1.27 & -0.27 \\
$\Delta(\mathrm{c}+\mathrm{i})_{1} \mathrm{t}$ & $\mathrm{df}=22$ & $\mathbf{R}^{2}=0.72$ \\
\hline $\mathrm{k}=-0.61$ &
\end{tabular}

* Model estimated using Cochran-Orcutt technique.

** $\mathrm{mp}$ represents purchases of services of military and defense civilian personnel.

gression). The war-mobilization variable does a good job in both equations. Private aggregate demand does considerably better in the first model. The coefficient for the electoral variable performs very well again, although it is somewhat higher for capital spending than for labor compensation. This too is an anticipated result, as the former is more easily manipulable than the latter. (In fact, the reverse result for the 'organizational' variable is a natural corollary to this finding.)

Our model therefore predicts not only to aggregate defense purchases of goods and services, but, with some slight differences, to purchases for each category separately. After taking up the question of the impact of defense spending for employment within the US economy, we shall return to a further discussion of the meaning of our findings.

\section{The domestic impact of defense spend- ing: the case of unemployment}

It might be useful at this stage to assess how beneficial military spending actually is in terms of its domestic impact. We have presented some rudimentary evidence suggesting that defense expenditures are associated with growth in national income. Our measure of national income was GNP per capita (expressed in real terms), i. e. the total dollar value of goods produced and 
services rendered within the US economy divided by the size of the nation's population.

GNP per capita is of course a simple and widely reported statistic and as such is one to which voters can easily relate and respond. Its impact, furthermore, seems to lie in its fluctuations rather than its levels (a reflection, according to James Tobin, of the fact that 'a first derivative mentality is strong in American politics' (1974, p. 20).

A number of caveats should be provided with respect to this measure of national economic performance. It provides, first of all, no information concerning income distribution and says little about the structural underpinnings of the economy. Furthermore, it tells us nothing about the externalities and opportunity costs associated with the expansion of economic activity. ${ }^{16}$ However, one thing usually associated with rapid growth in national income is a corresponding increase in levels of employment. ${ }^{17}$ This is in fact one of the beneficial domestic effects most frequently attributed to military spending by its major proponents. ${ }^{18}$

Estimates vary as to the number of people whose employment is somehow related to the military effort. This dissensus generally follows from disagreements regarding the multiplier effects attendant to military spending. One estimate of the full effect of defense spending on US unemployment is reported by Best and Connolly (1976, pp. 55-56). By their estimates, in CY 1970 , with 2.9 million people in the armed forces, 1.2 million civilian employees in the Department of Defense, and 3 million employees in defense industries (principal contractors), a total of 7.1 million people were directly employed through the US defense effort. Added to this, they contend, would be the efforts of the defense multiplier. They argue that for each job created directly by defense spending (in both the public and private sectors), another job will be created in private industry (job multiplier equals one). Thus, by their estimates, the total level of employment attributable to defense spend- ing was over 14 million. Thus, if one adds the 7.9 million unemployed in CY 1970 to the approximately 14 million of Best and Connolly, the total level of unemployment would be some 22 million, or $26 \%$ of the labor force (an unemployment level slightly greater than any experienced at the nadir of the Great Depression). The year 1970, however, was an exceptional year since Vietnam involvement was at its height; a job multiplier of one might also be somewhat inflated. According to the Department of Defense the job multiplier effects may be equal to the more conservative figure of 0.5 in the year of expenditure (1978, p. 102). By this estimate, the employment level attributable to military spending in CY 1970 would equal approximately 10.8 million, and not 14.2 million.

We have estimated the level of employment generated by the military effort for a number of years under different multiplier assumptions. In Table $\mathrm{V}$, row (a) represents the total number of people (in thousands) whose employment is directly accounted for by defense spending, i. e. military personnel, DoD civilian employees, and people employed in defense industries; row (b) provides the sum of the previous figure and a 'conservative' multiplier effect of 0.5 ; row (c) repeats this for a 'radical' multiplier of unity; row (d) gives the total number of unemployed in the relevant year; rows (e) and (f), respectively, provide the total number of people who would have been unemployed had it not been for defense spending under both multiplier assumptions.

Table V. Some estimates of the employment effect of military spending in the United States

\begin{tabular}{lrrrr} 
& \multicolumn{1}{c}{1940} & \multicolumn{1}{c}{1955} & \multicolumn{1}{c}{1965} & 1976 \\
\cline { 2 - 5 } $\begin{array}{l}\text { (a) Direct } \\
\text { jobs }\end{array}$ & $1,028.0$ & $6,935.0$ & $5,935.0$ & $4,817.0$ \\
(b) a+a*0.5 & $1,542.0$ & $10,430.0$ & $8,902.5$ & $7,225.5$ \\
(c) a+a*1.0 & $2,056.0$ & $13,906.0$ & $11,870.0$ & $9,634.0$ \\
(d) Unem- & $7,720.0$ & $2,679.0$ & $4,287.0$ & $7,171.0$ \\
ployed & & & & \\
(e) d+b & $9,262.0$ & $13,109.0$ & $13,190.0$ & $14,397.0$ \\
(f) d+c & $9,776.0$ & $16,585.0$ & $16,157.0$ & $17,906.0$ \\
\hline
\end{tabular}


According to these figures, military related employment levels have been quite high in the post-war period. Even including 1940, the four year average produces a figure of just over 7 million for the 0.5 multiplier, and over 9.3 million for the 1.0 multiplier. These are substantial figures and would be even more so were we to focus exclusively on the post-war period. The truly relevant question, however, should in our opinion be the following: does military spending make a significantly different contribution to the reduction of unemployment than would other, more socially useful, types of expenditure? What effect, for example, would the same dollar produce were it allocated to some other form of federal spending (e. g., education), or had it, say, been channeled down to state and local governments?

Two recent studies, one conducted by the Public Interest Research Group in Michigan (PIRGIM), the other by the Center for Defense Information, have recently addressed this question. Both conclude that military spending is not an efficient way of generating employment. The PIRGIM (1978) report undertook a comparison of the number of jobs created by public expenditure for various purposes. The results are presented in Table VI: the obvious conclusion is that defense spending fares rather poorly as a vehicle for job creation.

Table VI. Jobs created by $\$ 1$ bill. of expenditures/PIRGIM.

\begin{tabular}{lr}
\hline Job Corps & 145,000 jobs \\
Teachers & $76,000 "$, \\
Nurses & $85,000 "$, \\
Police & $73,000 "$, \\
Fire & $70,000 "$ \\
Defense & $58,000 "$, \\
(Military pers.) & \\
\hline Source: PIRGIM &
\end{tabular}

The unimpressive performance of the military dollar is, in all likelihood, due to the fact that the sum of compensation, equipment and associated costs is higher in the military sphere than in most others. The (1977) study conducted by the Center for
Defense Information gives a comparable picture of the performance of defense spending in the reduction of unemployment, as it appears that several obvious alternative types of spending would generate more jobs than does defense (see Table VII).

Table VII. Number of jobs created by $\$ 1$ bill. of expenditure (CDI).

\begin{tabular}{ll}
\hline Public Service Employment & 98,000 jobs \\
Anti-Recession Aid to State & \\
and Local Governments & $71,000 "$ " \\
Civilian Production & $53,000 "$ \\
Defense Spending & $45,800 "$ \\
\hline
\end{tabular}

Source: Center for Defense Information p. 3.

The discrepancy between the two figures for defense related employment is due to the fact that they were computed for different years (the CDS computations are based on 1978 estimates, while those of PIRGIM predate this by several years). Neither study seems to take job multiplier effects into consideration. This, however, would not alter the conclusions very drastically. Even if we were to make the extreme assumption that the military multiplier were equal to one, and that no multiplier effect existed for other categories of spending, defense would rank only second in either Table. Under more plausible assumptions it would do even less well.

\section{Conclusions}

The appropriate conclusion seems to be that while defense spending can perform a discernible economic function, this could be somewhat better accomplished by non-military forms of spending, at least as far as employment is concerned. The question is then obvious: why should any reliance be placed on military spending in this context? A first answer is that exclusive reliance is certainly not placed on this sort of expenditure; numerous other ways of stabilizing the economy (e. g., by manipulating the money supply) are available and are used. Nevertheless, defense outlays do seem to have a 
number of advantages in this regard, of which we shall list three in particular: ${ }^{20}$

(1) Independently of its effects in the postwar period, massive government spending generally has not been welcomed by the US public. Defense spending, however, can be rather easily justified to the tax-paying electorate as national security needs can most often be plausibly invoked.

(2) Military spending is highly expandable as it does not, like many other forms of government spending, compete directly with private investment. Its supplements but does not supplant the private sector. ${ }^{21}$ Thus, its expansion will not undermine business confidence - an outcome which would only cut short any upswing.

(3) Many military goods have the advantage of possessing a rather short life-span and must be frequently replaced to avert obsolescence. As most of the machinary is specific to a given type of armament, it must be replaced almost as frequently as the final product. The scope for capital purchases is thus quite large.

Furthermore, despite the considerable lag between the time when the development of a new weapon (or other system) is initiated and its actual production, employment and other effects appear from the moment obligations are first incurred. From that moment, orders are placed, subcontracting agreements can be signed, hiring gets underway, and so forth. ${ }^{22}$ Thus, results are produced quite rapidly. Also, politicans can in many instances control these effects rather well. While the influence of elected officials is obviously greatest at the stage of appropriations, they can also influence the timing of actual obligations and even spending - e.g., via the Chief Executive's control of the O.M.B.

These are all compelling advantages for an incumbent despite the restricted value of this tool of macroeconomic policy. They seem to demonstrate that policy is neither the art of the optimal nor of the possible, but primarily the practice of the expedient.

It is thus possible to explain the dual domestic function of military spending as a means of: (a) stimulating the economy in anticipation of electoral benefits, and (b) compensating for shortfalls in private consumption and investment. The level of our knowledge is, however, still rough and much scope exists for further study. The 'guns vs. butter' trade-off has not been sufficiently studied. It would also be very interesting to delve more deeply into the various means by which the volume, location, and timing of spending can actually be influenced by incumbents (for example, by the use of 'supplementary appropriations'). Also, while the 'action-reaction' hypothesis does not seem particularly useful, other models of a less regular form of response to Soviet spending should be examined.

\section{NOTES}

1. See his Arms and Insecurity (1960). A good discussion of this and other works by Richardson is to be found in Rapoport's review article (1957). See also Caspary (1967) and Zinnes and Gillespie (1976, part III). Of related interest is Huntington's (1958) article.

2. Much of the relevant writing is based on the work of Wildavsky and his associates, the best summary being his 1975 volume; as well as on the work of Graham Allison (1971, 1975). An application of this perspective to the issue of military expenditure is to be found in John P. Crecine and Gregory W. Fisher's paper on the US Defense Department (1973).

3. As Allison summarizes the approach: 'Major lines of organizational action are straight, i.e., behavior at one time is marginally different from that behavior at $\mathrm{t}-1$. Simple-minded predictions work best: Behavior at $t+1$ will be marginally different from behavior at the previous time' (1975, p. 58).

4. Data on military spending in this article will be defined as total purchases of military related goods and services. For 1948-1974: 1975 Statistical Supplement to the Survey of Current Business; for 1975-1976, Survey of Current Business (July 1977).

5. 1972 will be the base year for the calculation of constant prices.

6. We believe that the basically a-theoretical nature of this measure is justified by our interest in including wartime mobilization exclusively for purposes of statistical control. We do not attempt to explain its progression. 
7. See Tufte (1975). For on-year congressional elections and presidential elections, see his more recent work, The Political Control of the Economy, Chap. 5. See also Ray C. Fair's 1978 article 'The Effect of Economic Events on Votes for the President', George Stigler's 1973 paper 'General Economic Conditions and National Elections', and Susan Leppe's 1974 paper 'Voting Behavior and Aggregate Policy Targets'.

8. See Tufte $(1978$, p.4), and William D. Nordhaus, 'The Political Business Cycle'. Related studies are: Duncan MacRae's 'A Political Model of the Business Cycle', James R. Crotty's 'Specification Error in Macro-Econometric Models: The Influence of Policy Goals', Douglas A. Hibbs Jr.'s 'Political Parties and Macroeconomic Policy', and Bruno Frey's Modern Political Economy (esp. Parts III and IV).

9. The provision of such an analysis may well mark the point where the responsibility of the political scientist stops and that of the professional economist begins.

10. Data on GNP per capita from Economic Report of the President, 1976. Note that the dollar values employed in all of our statistical analyses are expressed in constant prices with the base year being 1972 .

11. The reader may verify this by performing the relevant differentiation.

12. By manipulating military spending, a government is acting on aggregate demand. While this is a major part of regulatory macroeconomic policy, it might be less appropriate for small and open economies (such as those of Western Europe) than it is for the US economy. Assar Lindbeck (1976), for example, suggests that instead of acting on aggregate demand, the following alternatives are available: (1) policies designed to influence relative prices, (2) market-improving and mobility-increasing policies, (3) managing supply, and, (4) 'selective demand management'. For this reason, military spending should not be expected to play a similar role in most other industrialized democracies as it does in the US.

13. To quote Lindbeck (1976, p. 13) again, 'the government will usually cut back aggregate demand after the election in order to bring down the rate of inflation, to squeeze out inflationary expectations and hence to shift down the short-term Phillips curve, as well as to reduce deficits in the current account, well in time before the next election, so that new expansionary actions can again be undertaken before that election.' See also Nordhaus (1975).

14. Data on private consumption and investment are taken from Economic Report of the President, 1977.

15. Data for capital items and personnel com- pensation are from various issues of Defense Indicators.

16. A measure more reflective of these has been proposed by Tobin and Nordhaus in, 'Is Growth Obsolete?' (1972).

17. According to the well-known 'Okun's Law' a $3 \%$ growth in GNP in the United States is needed to reduce unemployment by $1 \%$. See Arthur Okun (1970), p. 240.

18. The reader will recall that this was one of the main arguments advanced against abandoning B-1 bomber production by its supporters.

19. Data are from the March issues of Monthly Labor Review, for the relevant years.

20. These reasons are most often advanced by radical economists. See, for instance, Murray Weidenbaum, 'Defense Expenditures and the Domestic Economy', in Mansfield (ed.) (1968); Michael Reich (1972), pp. 296-303, and Cypher (1974).

21. This point had been initially advanced by Michael Kalecki in his 1943 article, 'Political Aspects of Full Employment'.

22. The same effect may, to a certain extent, be achieved through simple obligation as by actual expenditures (Greenberg 1967, Lee 1970), a matter to which governments appear oblivious.

\section{REFERENCES}

Allison, G. 1971: Essence of Decision. Boston: Little, Brown.

Allison, G. 1975: "Conceptual Models and the Cuban Missile Crisis', in W. D. Coplin and C. W. Kegley Jr. (eds). Analyzing International Relations. New York: Praeger, pp. 49-79.

Anderson, M. 1978: The Empty Porkbarrel. Mimeograph, East Lansing: Public Interest Research Group in Michigan.

Best, M. H. \& W. Connolly 1976: The Politicized Economy. Lexington, Mass.: D. C. Heath.

Caspary, W. 1967: 'Richardson's Model of Arms Races: Description, Critique and Alternative Model', International Studies Quarterly, Vol. XI.

Center for Defense Information 1977: 'Jobs and the Pentagon: Is Military Spending Good for the Economy', The Defense Monitor, Vol. 6, No. 7.

Crecine, J. P. \& G. W. Fisher 1973: 'On Resource Allocation Porcesses in the US Defense Department', in C. P. Cotter (ed). Political Science Annual, Vol. 4. New York: BobbsMerrill.

Crotty, J. R. 1973. 'Specification Error in MacroEconometric Models: The Influence of Policy Goals', American Economic Review. Vol. 63, pp. 1025-1030.

Cusack, T. R. 1978: The Major Powers and the 
Pursuit of Security in the Nineteenth and Twentieth Centuries. Ph. D. Thesis, University of Michigan.

Cypher, J. 1974: 'Capitalist Planning and Military Expenditures', The Review of Radical Political Economics, Vol 6, pp. 1-19.

Fair, R. C. 1978: 'The Effect of Economic Events on Votes for the President', The Review of Economics and Statistics, Vol. 60, pp. 159-173.

Frey, B. S. 1978: Modern Political Economy. Oxford: Martin Robinson.

Galbraith, J. K. 1967: The New Industrial State. New York: Penguin.

Greenberg, E. 1967: 'Employment Impacts of Defense Expenditures and Obligation', Review of Economics and Statistics, Vol. 41, pp. 186197.

Hibbs, D. A. Jr. 1977: 'Political Parties and Macroeconomic Policy', American Political Science Review, Vol. 71, pp. 1467-1487.

Hitch, C. \& R. McKean. 1961: The Economics of Defense Spending in the Nuclear Age. Cambridge: Harvard University Press.

Huntington, S. P. 1958: 'Arms Races: Prerequisites and Results', Public Policy, Vol. 8, pp. 41-86.

Johnston, J. 1972: Econometric Methods, 2nd ed. New York: McGraw-Hill.

Kalecki, M. 1943: 'Political Aspects of Full Employment', Political Quarterly, Vol. 4, pp. 322331. Reprinted in Kalecki, M. 1977: Selected Essays on the Dynamics of the Capitalist Economy. Cambridge: Cambridge University Press.

Kramer, G. 1971: 'Short Term Fluctuation in US Voting Behavior, 1896-1964', American Political Science Review, Vol. 60, pp. 131-143 (revised version appearing in No. 68877, Bobbs-Merril Reprint Series in Political Science).

Lee, M. L. 1970: 'Impact, Pattern and Duration of New Orders for Defense Products', Econometrica, Vol. 38, pp. 153-164.

Lepper, S. J. 1974: 'Voting Behavior and Aggregate Policy Targets', Public Choice, Vol. 18, pp. 67-81.

Lindbeck, A. 1976: 'Stabilization Policies in Open Economies With Endogenous Politicans', American Economic Review, Vol. 66, pp. 1-19.

MacRae, D. 1977: 'A Political Model of the Business Cycle, Journal of Political Economy, Vol. 85.

Nixon, R. M. 1962: Six Crises. New York: Doubleday.

Nordhaus, W. D. 1975: 'The Political Business Cycle', Review of Economic Studies, Vol. 42, pp. 169-190.

Okun, A. 1970: The Political Economy of Prosperity. New York: Norton.

Organski, A. F. K. \& J. Kugler with D. J. Fox. 1978: 'Deterrents, Deterrence and Arms Races', mimeograph, University of Michigan.
Ostrom, C. W. Jr. 1977: 'Evaluating Alternative Foreign Policy Models: An Empirical Test Between an Arms Race Model and an Organizational Politics Model', Journal of Conflict Resolution, Vol. 21, pp. 235-265.

Rapoport, A. 1957: 'Lewis Fry Richardson's Mathematical Theory of War', Journal of Conflict Resolution, Vol. 1, pp. 249-299.

Reich, M. 1972: 'Does the US Economy Require Military Spending?', American Economic Review, Vol. 62, pp. 296-303.

Richardson, L. F. 1960: Arms and Insecurity. Chicago: Quadrangle Books.

Russett, B. 1970: What Price Vigilance? The Burden of National Defense. New Haven: Yale University Press.

Smith, R. P. 1977: 'Military Expenditures and Capitalism', Cambridge Journal of Economics, Vol. 1, pp. 61-76.

Stigler, G. 1973: 'General Economic Conditions and National Elections', American Economic Review, Papers and Proceedings, pp. 160-167.

Tobin, J. 1974: The New Economics One Decade Older. Princeton: Princeton University Press.

Tobin, J. \& W. Nordhaus. 1972: 'Is Growth Obsolete?' In National Bureau of Economic Research, Fiftieth Anniversary Colloquium New York: Columbia University Press.

Tufte. E. 1975: 'The Determinants of the Outcome of Midterm Congressional Elections', American Political Science Review, Vol. 64, pp. 812-826.

Tufte, E. 1978: The Political Control of the Economy. Princeton: Princeton University Press.

US Bureau of Economic Research 1975: 1975 Statistical Supplement of the Survey of Current Business. Washington DC.

US Bureau of Economic Research 1977: Survey of Current Business. Washington DC.

US Bureau of Economic Research, various numbers: Defense Indicators. Washington DC.

US Council of Economic Advisors 1976: Economic Report of the President 1976. Washington DC: Government Printing Office.

US Council of Economic Advisors 1977: Economic Report of the President 1977. Washington DC: Government Printing Office.

US Department of Defense, Office of the Assistant Secretary 1978: National Defense Budget Estimates for FY 1979.

US Department of Labor, various numbers: Monthly Labor Review.

Weidenbaum, M. 1968: 'Defense Expenditures and the Domestic Economy', in E. Mansfield (ed). Defense Science and Public Policy. New York: Norton.

Wildavsky, A. 1975: Budgeting: $A$ Comparative Theory of Budgetary Processes Boston: Little, Brown. 
Wohlstetter, A. 1974a: 'Is There a Strategic Arms Race?', Foreign Policy, No. 15, pp. 2-21.

Wohistetter, A. 1974b: 'Rivals But No Race', Foreign Policy, No. 16, pp. 48-81.
Zinnes, D. \& J. Gillespie (eds) 1976: Mathematical Models in International Relations. New York: Praeger. 